\title{
Customary Land Ownership and Gender Disparity Evidence from the Wa Municipality of Ghana
}

\author{
Elias Danyi Kuusaana \\ Department of Real Estate and Land Management, \\ University for Development Studies, \\ Wa, Ghana. \\ Email: eliaskuusaana@yahoo.com \\ Joseph Kwaku Kidido \\ Department of Land Economy, \\ Kwame Nkrumah University of Science and Technology \\ Kumasi, Ghana \\ Email:jkidido@yahoo.co.uk \\ and \\ Eniam Halidu-Adam \\ Public and Vested Land Management Division, \\ Lands Commission, \\ Wa, Ghana. \\ Email:eniam20@yahoo.com \\ DOI:http://dx.doi.org/10.4314/gjds.v10i1\&2.4
}

\begin{abstract}
Studies draw attention to gender inequalities in land tenure. While some insist that gender inequalities in land tenure exists others do not. This paper discusses a study that examined gender issues in customary land ownership in the Wa Municipality. It sought to understand and find ways of bridging the gender gaps, if any. A survey covering 151 respondents comprising Chiefs, Tendamba, women and family heads was undertaken. The research revealed significant disparities between men and women regarding access to and ownership of land. Only 38\% of female respondents owned land as compared to $68 \%$ of the male respondents. This was mainly attributed to the patrilineal system of inheritance. It also revealed that the inequality in access to land was due to financial constraint and, rapid urbanization as well as the high illiteracy
\end{abstract}


rate among women. A number of recommendations have been made for enhancing women's access and ownership of customary land in the Wa Municipality and for promoting gender inclusiveness.

KEYWORDS: Gender Equality, Access and Control, Systems of Inheritance, Customary Ownership, Land Tenure

\section{Introduction}

Land is a primary source of wealth, social status and power. It is the foundation for food production, shelter provision and economic activities and as such virtually every individual depends directly or indirectly on land for their livelihood. Thus, every individual needs to be given equal and equitable opportunities without undue discrimination. In Ghana, $80 \%$ of the total land area is customarily owned by clans, stools, skins and families. The state owns $18 \%$ while the remaining $2 \%$ is held in dual ownership by the state: the beneficiary interest being held by the community and the legal right being vested in the state (Ministry of Justice, 2000; cited in Adiaba, 2006). Access to and ownership of land within the customary sector is primarily based on membership to a particular landholding community. This is because "land under customary tenure was considered as a resource that all community members should have access to land in order to subsist" (Pottier, 2005: 58). However, women do not enjoy equal rights to land; they have only secondary use rights to land and they can only gain access to land through their husbands, brothers and sons (Kameri-Mbote, 2005).

Some customary inheritance systems such as patrilineal succession limit or even exclude women's succession rights to land. Under the patrilineal succession systems, property devolves only through male lines (from father to son or father to brothers), but wives and daughters have no inheritance rights to land. Matrilineal inheritance is through the mother's lineage. In this regard, lineage property including land can be inherited only by a member of the matrikin while self-acquired property can be a given as gift to anyone the deceased so desires. Property and status are hence transferred from the mother's brother to sister's son. Though this inheritance system comes with customary obligations imposed on the successor towards the surviving widow and her children these are often ignored in practice. This notwithstanding, women within matrilineal societies have relatively better access to and control over land compared to those of patrilineal society. Quan (2006) in acknowledging that matrilineal systems provide greater opportunities in social networks for women to access land was fast to indicate that these benefits are being widely eroded. This is because lineage heads often discriminate against them in favour of men (Manuh, 1984).

In the Wa Municipality, customary land issues are determined by male-dominated institutions such as chieftaincy, kinship and lineage, and priestly system (Kuusaana, 2007). Thus, women's rights of access to land are highly dependent on social ties, which 
link them to those with primary rights over customary land; the men. As noted by Toulmin and Quan (2000) divorcees or widows may be forced to relinquish matrimonial lands even if they have investments on them. Such investments in the Wa Municipality may include housing, seasonal food crops or small scale tree crop plantations like cashew and mango. Dowuona-Hammond (2003) opined that as a result of the lack of insecurity of women's access to land, they are not able to meet their various necessities of life (food, shelter and clothing).

The customary land tenure system is however not the only way of gaining access to land; one can acquire land through purchase, lease or tenancy from the government, skin or stool or families. Even though these ways of acquisition could be the most secure ways to women's land ownership, there are financial constraints. Women experience higher levels of poverty, have greater burdens, lower rates of access to and utilization of productive resources (Dowuona-Hammond, 2003). This shows that the poverty status of women may be an underlying factor for their unequal access and ownership of land resources (Owusu, Kwami \& Tagoe, 2007) especially amidst the commercialization of land.

\section{Women's Land Rights under the Customary Land Tenure}

Under the customary land tenure system in Ghana, control over resources, generally, follows clearly segregated patterns based on traditional norms (Dowuona-Hammond, 2003). The norms operate in a way that they limit the rights of women compared to men. Women's access and control over resources including land are therefore determined by male-centred kinship institutions and authority structures which tend to restrict women's land rights in favour of men (Toulmin, 2003; cited in Owusu et. al, 2007). It is also the case that the stability of women's marriage is critical to their access to agricultural resource from their matrimonial homes. Divorcees and widows face discrimination in accessing to land (Bortei-Dorku, 1990). The lack of clearly defined social identity of women and strangers also weaken women's rights of access to land.

Niessen (1985) has commented on the social identity of women's membership in their natal and matrimonial homes. In his view, women are associated with both families but are not absolute members of either family and thus have no clearly defined social identity. Another relevant study on gender and land rights is by Duncan and Brants (2004). They investigated the extent to which men and women have access to and control over land in seven districts of the Volta Region of Ghana. Even though most respondents indicated that both men and women had equal access to land in their various communities, their findings showed significant difference with regard to the extent of men's and women's access to land in these communities. Their study revealed that while men have full ownership rights to land, women often had partial or conditional access rights. In a study on the Ho Municipality of the Volta Region, Sewornu (2010) confirmed the differences of the extent of men and women access right to land. 
Both the Sewornu's (2010) and Duncan's and Brants' (2004) studies found that ownership of land was largely vested in lineage or clan and family units and managed by male lineage heads. Factors such as inheritance system, local traditions and customs, decision-making powers, perceptions and marital status among others were identified to affect men and women access to land. By and large these factors tend to favour men while placing women at a great disadvantage since issues about women are placed secondary to the decisions (Duncan and Brant, 2004).

According to Owusu and associates (2007), in the Volta and Central regions, land tenure dynamics and livelihood are significantly male-biased. It was also established in a study by Bugri (2008) that more males (66\%) than females (55\%) perceived customary land tenure to offer better security for agricultural production. This phenomenon was attributed to the religious beliefs and practices between male and females in their communities. Naba Amoa, as cited in Bugri (2008), on the contrary underscored this assertion in the Upper East Region.

However, in a study by Kasanga and associates (1995), which covered Wa, Nadowli and Kumasi, they concluded that existing tenure systems do not present significant obstacles to women's access to agricultural land or inhibit agricultural development among women. They also stated that women who inherit through matrilineal lines for instance in Kumasi usually have an urge over men in knowing the extent and boundaries of family land holdings and are more inclined to pass on such farms to their daughters and granddaughters (Kasanga et.al ibid: cited in Ministry of Justice, 2003).

In a study by Quisumbing, Aidoo and Otsuka (1999) in the Central Region, it was established that, land is increasingly being transferred to wives and children and even family lands are transferred to them. This is however done with the consent of the family members particularly after the lands have been wholly or partially planted with cocoa trees. This type of transfer can however best be seen as gifts. We are however of the view that, the roots of women access to customary land should be more than just gifts, since gifting is no longer attractive due to the commoditization and commercialization of land.

Legal pluralism induced land conflicts exist. There are conflicts between traditional norms and national laws when land rights are considered. At the local level, land issues are largely custom-based and these are enforced by community members particularly in the rural areas. National policies and laws granting equal access to productive resources are essential for gender equity. However, for these rights to appear legitimate and be enforceable, they will have to be accepted by the local communities.

\section{Women and Customary Land Tenure Security}

Land tenure as described by FAO (2002) simply determines who can use what resources for how long and under what circumstances. Tenure security in general terms could be seen as an individual's perception of his or her right to a piece of land on a continual basis, 
free from interference from outside sources as well as the ability to reap the benefits of investments in land (ISSER, 2005). Bugri (2008) defines land tenure security as "the ability to continually cultivate land without interference." This probably presents an acceptable definition for both males and females. Land access refers to the availability of land and ownership security, desirable physical and economic attributes, reliable credit and property information and the level of transparency and fairness of transactions (Ahene, 2009). Generally, rights of access to land can take the form of use rights, control rights and transfer rights (Ostrom and Hess, 2007). The use rights involve the right to peaceful and beneficial enjoyment of property as well as the right to benefit financially from the sale of the produce. The control rights refer to the rights to exclude others from interfering with the use of land. The transfer rights involve the right to sell or mortgage the land or to convey the use and control rights of land to others through intra community allocations and reallocations (Ostrom \& Hess, 2007).

Even though all these explanations boil down to reasonable control of land, most women who have access to land are not given the privilege to control and transfer lands, they merely use it under restricted conditions and inadequate security of tenure. KameriMbote (2005) noted that women traditionally do not own land and the best rights they could have are the usufruct rights which hinge on the nature of the relationship between them and their male counterparts either as husbands, brothers, fathers or such other male relative. She further noted that, such land rights could be truncated at any time as it is dependent on the whims of such male benefactors. This situation affirms the marginal and vulnerable nature of women's land rights as compared to the men (Bugri, 2008). According to ISSER (2005), 96\% of men have control over land in the Upper West Region. Thus land issues are in their hands and women would have to depend on them and this undermines their security of tenure.

\section{Impact of Inadequate Access to Land on Women's Livelihoods}

According to IFAD (1998), women's limited land access affects the crops they can grow. They do not plant tree crops on their lands since they could easily lose their lands and all the profits accruing thereof. In fact, the maturity of economic trees can be an incentive for losing the land as the land owner develop interest in it and can find reasons to take it back. IFAD also emphasises that it restricts women's access to credit from formal sources as they do not have title to land and as such cannot use it as collateral. Even in cases where women do have title to land, there is evidence that women cannot take full advantage of the established credit since credit institutions tend to be male-oriented and discriminate on cultural and social biases against women (FAO, 2005; cited in Owusu et al, 2007). Financial institutions are not inclined to advance loans to the poor especially women due to high transaction costs associated with micro-finance. As a result women are often unable to make transactions without a male relative's consent. Again, IFAD (2005) revealed that women insecurity and inaccessibility to land discourages land conservation since ecofeminists argue that women are better environmental managers than men. 
In developing countries, women are usually very dependent on common property resources for water, firewood, compost for farmland and wild herbs, mushrooms, fruits and nuts, as it is usually their responsibility to ensure that the family is supplied with these goods. However, when these commonly held resources become scarce and property rights are exerted because of a perceived market value, their control tends to be assumed by men, although women's role as the supplier to the family of these resources does not change (Agarwal, 1989). Even though an increase in the value of land should inure to the advantage of the women holding it, it is rather the contrary. It largely motivates land confiscation from women who only have use rights and title to customary land.

Formal land title registration is another area that poses risks to women's access to land. According to Hilhorst (2000), women and other secondary rights holders run a serious risk of being denied legal the recognition of their customary rights with the implementation of land titling programmes. These people cannot register their lands because they have no paramount interest in the land and attempting to register the land may be likened to the claim of ownership. Lack of access to land by women according to Kameri-Mbote (2005) places them in a precarious position in terms of their survival and livelihoods, and stifles their effective role and contribution to national development. Kameri-Mbote further opined that "with agriculture and other land based natural resources being the main sources of livelihood, the consequences for women not owning, controlling or accessing land are grave" (Kameri-Mbote, 2005:1).

\section{Land Ownership Pattern in Wa}

Customary rules exert the most significant influence on land ownership in the Upper West Region. According to ISSER (2005) there are six land ownership types in the Region. From the statistics below, ISSER identified that most of the lands in the Upper West Region are under family ownership. This position is corroborated by Kunbuor (2000) that the position of chiefs and Tendamba has now reduced to family possession of lands among the Dagaaba of Ghana. In the Wa Municipality, family land holding is in the hands of the Kpaguri, Sokpeyiri, Puohuyiri and Suuriyiri sections of Wa (Kuusaana, 2007). See Table 1 below.

Table 1: Ownership Pattern in the Upper West Region

\begin{tabular}{|l|l|}
\hline Ownership Types & Percentage \\
\hline Family & $41 \%$ \\
\hline Individual & $35 \%$ \\
\hline Tendamba & $23 \%$ \\
\hline Chiefs & $0.2 \%$ \\
\hline Traditional Council & $0.2 \%$ \\
\hline Migrants & $0.2 \%$ \\
\hline
\end{tabular}

Source: ISSER, 2005 


\section{Methodology}

The study used both secondary data from a previous study by ISSER (2005) and primary data collected in 2009 by the authors. Primary data was collected mainly through interviews with key stakeholders such as Chiefs, Endameba and some women. According to the 2010 Population and Housing Census (GSS, 2012), Wa had a total population of 107,214 which included 54,218 (50.57\%) females and 52,996 (49.43\%). A sample size of 151 respondents were used for the study out of a total population of 107, 214. Female respondents were 88 representing $58 \%$ of the sample size while 63 representing $42 \%$ were males. Chiefs and Endameba were purposively sampled whiles the women and other male respondents were selected for interview using a combination of sampling techniques such as clustering, systematic sampling, snowballing in arriving at the sampled population.

Out of the total number of female respondents, 35.23\% had no level of education, $17.04 \%$ had primary education, 22.63\% had junior high /middle school education, $11.36 \%$ had senior high education, and $13.64 \%$ had tertiary education. Majority of male and female respondents were married representing $57.14 \%$ and $68.18 \%$ respectively. Also the data revealed that $54.86 \%$ of the male respondents were farmers, $12.70 \%$ engaged in trading activities, $20.16 \%$ were civil servants and $14.28 \%$ engaged in other activities like masonry and blacksmithing. From the female respondents, $44.09 \%$ were farmers, $22.73 \%$ were traders, $11.09 \%$ were civil/public servants, $14 \%$ engage in occupations like hairdressing and dressmaking and $8.09 \%$ of the female respondents were unemployed or housewives. The study was carried out in the Wa Municipality because of the peculiar nature of patrilineal inheritance in the area and perceived unequal access to and ownership of land. It was specifically restricted to gender disparity with respect to access, control and ownership of land. This is to allow for recommendations to guide future land policy reforms so as to enhance women access to and ownership of land.

\section{Presentation and Discussion of Data}

\section{Modes of Land Acquisition in Wa}

Land in the Wa Municipality and the Upper West Region in general can be acquired through inheritance, outright sales, gifting and leasing. However, patrilineal inheritance accounts for $97.1 \%$ of land acquisition in the Region (ISSER, 2005). Men are usually put in control of land under the patrilineal inheritance system whilst women may enjoy secondary rights. A survey carried out by ISSER (ibid) also revealed that purchases are the second major way of acquiring land in the study area. From our study, $64 \%$ of the male respondents had access to family lands through inheritance against $14 \%$ of the female respondents.

Also, with regards to ownership of land only $38 \%$ of female respondents owned land as compared to $68 \%$ of the male respondents (Table 2). From the results of our survey in 
the Wa Municipality, it emerged that land access and ownership is in favour of males and therefore has implications for women empowerment, gender equity in land resource ownership and use. Women's contributions, especially in food production and family income generation are greatly impaired by this wanton disparity in land ownership skewed in favour of men. This is so because the productivity of women especially in the supply of family food and generation of income for households in the peri-urban and the rural areas revolves largely around land. As noted by Kameri-Mbote (2005:1) "with agriculture and other land based natural resources being the main sources of livelihood, the consequences for women not owning, controlling or accessing land are grave." Lack of adequate productive land units seriously undermines women's contributions which tend to deny the society the benefits of their productive efforts.

Table 2: Modes of Acquisition Responses

\begin{tabular}{|l|l|l|}
\hline Mode of acquisition & Male & Female \\
\hline Inheritance & $64 \%$ & $14 \%$ \\
\hline Rental & $0 \%$ & $17 \%$ \\
\hline Cash purchase & $24 \%$ & $33 \%$ \\
\hline Borrowing & $5 \%$ & $29 \%$ \\
\hline Gift & $8 \%$ & $8 \%$ \\
\hline Others & $0 \%$ & $0 \%$ \\
\hline
\end{tabular}

Source: Field Survey, 2009

Contrary to the perception that women in the Wa Municipality do not inherit lands, it was revealed that $14 \%$ acquired their lands through inheritance. These women however attributed their success in acquiring parcels through hard work and their ability to stand up to the men in their families to have their equitable share of their inheritance. Also 33\% of the female respondents acquired their lands through cash purchase, $17 \%$ of the female respondents acquired their lands through rental, 29\% acquired it through borrowing and $8 \%$ of the respondents had their lands through gifts (Table 2). Women resort to these ways of acquiring lands for farming because local customs do not guarantee them rights to own family land. Women, who can afford, prefer to buy land from the emerging land market.

In general, both married and unmarried women lack rights to own land. Women only have access to wild fruit trees like dawadawa, shea nuts, baobab among others to gather them for household consumption. However, they do not have any control rights over these fruit trees. They cannot sell them unless they are authorized or given the permission to do so. Married women in their husbands' homes are only considered as helping hands; they do not have direct access and control of lands in their marital homes just as in their natal 
homes. A husband can however give a portion of his farm land to his wife to cultivate but she is restricted in the extent of usage (qualitative field data, 2008).

\section{Land Relations in the Wa Municipality}

Lands in the study area are family lands belonging to the Endameba. The Endameba are the first settlers and accordingly wield the power of control; use and allocation of land over all other people including even chiefs of such areas (Interview with Chiele Naa Bandanaa, 2007; cited in Kuusaana, 2007). In the Wa Municipality, all Endameba are men; hence women are relegated to the background when it comes to owning or taking decisions hinging on land.

\section{Land Size and Land Use}

Most of the respondents (68\%) did not know the sizes of their lands. For the few (32\%) who knew their land sizes, farm land sizes ranged from 1 acre to 30 acres. It was however revealed that large farms belonged to the men. The situation in the Wa Municipality reaffirms the findings of IIED (1999) which reported that, across West Africa and Sahelian Regions, women access land indirectly and the size of their landholding always smaller than the male counterparts. Again from the survey results, crops cultivated by women in the Wa Municipality are mainly maize, groundnut, yams and varieties of vegetables. They do not cultivate crops like cotton, cowpea and also poultry, fish farming and livestock rearing because they do not have the capital to do so. Women are financially constrained from large scale cultivation or mixed farming. They produce mainly to feed their families and only sell small quantities for income to cater for other needs.

\section{Factors Impeding Women's Access to and Ownership of Land}

\section{Customary Practices on Ownership of Property}

From the data collected, majority of females (74\%) and male (71\%) respondents admitted that women were restricted customarily in their ownership of land. The reasons were as follows:

- Traditionally women are regarded as non-permanent members of their natal homes who will marry and move out of the family. As a result they are not taken into consideration when allocating land to family members. Women's ownership of land in this respect, have the potential of claims from their husbands.

- In their marital homes, women are regarded as "properties/assets" that are owned by their husbands and brought from somewhere to be caretakers of their husbands' children and homes (qualitative field data, 2008). It therefore stands to reason that "properties cannot own properties." Hence women are not allowed to own properties since they themselves are considered assets. As helping hands to 
their husbands they help their husbands on their farms and perform their marital duties.

Under such circumstances, where women cannot own land as of right and are considered assets who cannot own property of their own, women are left no options within their families and kin.

\section{Customary Practices on Inheritance}

Qualitative data from the study further revealed that it is mostly men who inherit their fathers' lands and properties. When a father dies, his property devolves to the eldest of his sons and not the eldest child. It means that if a woman is even the oldest of the children she does not inherit her father's property. However, if all the deceased's children are minors then the land is inherited by the deceased's surviving brother(s) to be held in trust for the minors. This is done with the presumption that whoever inherits the property would take care of the sisters, mother and minor children of the deceased. The properties owned by a deceased who have only female children are completely inherited by the deceased's brother(s). Widows do not inherit their husbands' properties; they only rely on their sons who inherit their fathers' properties to cater for their mothers' needs. It is however noteworthy that though these are strict positions in custom; legal redress can be sought under the Intestate Succession Law, PNDCL 111. Section 4 of the PNDCL 111 provides that where someone dies intestate leaving an immovable property such as a house or a parcel of land, the surviving spouse (which may be the widow) and the children are entitled to that property. Thus, under the PNDCL 111, a widow is entitled to the property (house or land) of the deceased husband if he dies intestate. However, these legislative measures have often not being a common option for women due to illiteracy and in some cases societal scorn. The provisions for women under the Intestate Succession Law conflict with the customary arrangements of communities.

It was found that customary beliefs and practices on sacrifices to the 'land gods' (tengan mwime/mwini) are some of the factors impeding women's access to and ownership of land. Customarily, women are forbidden from performing sacrifices and rituals to the land and ancestral gods. This is premised on the fact that women are considered impure and since ownership is tied down to these practices, women are deemed incapable of owning lands.

\section{Economic Factors}

The study further revealed that there were other factors apart from customary factors that impeded women access to and ownership of land in the Wa Municipality. The major factor mentioned by both men (71\%) and women (75\%) respondents was financial constraints. Most women are not gainfully employed, they earn very little from their small farms and the petty trading activities. Hence they do not have enough money to purchase lands to compensate for what they have been denied by their families. Increasingly, the emergence of vibrant land markets and consequent land commoditisation in the last 
decade has worsened the position of women's land ownership. In a study by Gray and Kevane (1992) on land tenure system in sub-Saharan Africa, they attested to the fact that changing values of land affects women's access to land more than men. In their view as land increases in value, men and corporate groups dominated by men, including state authorities, find it in their interest in one way or the other to renegotiate with women or to take even their lands away from them.

\section{Knowledge on Land Rights}

It was evident from the responses that about $64 \%$ of the female respondents did not know about their land rights. This could be attributed to the fact that women's land rights are not customarily prescribed and institutionalised. Hence, they are not well appreciated and understood by even women themselves. According to them, the tradition that men are heads of the family still holds and that they have the sole responsibility of taking care of women and to provide them with food, clothing and shelter as tradition demands. They are just to help their husbands in whatever they do and perform their marital duties. It was further revealed that $76 \%$ of the female respondents knew there were some laws that seek to protect their rights even though some of them could not enumerate them. When asked about the effectiveness of these laws, $60 \%$ of them did not know because they have never made claims under these laws. Our findings are similar to that of Duncan and Brants (2004) in their study of the Volta Region of Ghana. They found out that $61 \%$ ( $n=183$ ) of respondents had not heard of the Intestate Succession Law (PNDCL 111) being applied but traditional inheritance practices. These we have already confirmed are inimical to women land access and property ownership.

\section{Urbanization in the Wa Municipality}

It was revealed from the study that rapid urbanization affected women's access, control and ownership to land. The Wa Municipality is fast growing and more agricultural land uses are now being changed to urban land uses i.e. residential, commercial and recreational uses and land prices are rising at a fast rate. As a result, land-owning-familyheads now prefer to sell lands for cash rather than give out lands as gifts to women. Hence, high value lands used by women are sold out and are being replaced by other less valuable lands far away from town where there are spare land available. Land transaction has become a lucrative business for land owners and unfortunately providing incentive for marginalization against women in possessing land.

\section{Impact of Women's Access to and Ownership of Land on their Livelihood}

\section{Women and their Livelihoods}

Qualitative data from our study revealed that the inability of many women to access and own land, has consequently reduced unmarried women in their natal homes to helping their male relatives on their farms in return for other forms of assistance when the need 
arises. Consequently, they tend to depend on them for their needs, which are rarely met. Those who have the privilege of getting lands from their fathers or brothers do not have secure rights over these lands; the lands are taken from them whenever they want to sell at higher prices, to pay debts or perform funeral or marriage rites. It also restricts women's access to credit from formal sources as they do not have land to be used as collateral. Even when titles exist, women socially and culturally are discriminated against (FAO, 2005). Poor women practically have no access to shelter credit. Financial institutions prefer to give big loans which the poor especially women cannot afford because their monthly incomes are too small for repayments required. As a result, women are often unable to make transactions without a male relative's consent (Quist, undated). This situation has caused most of the young and unmarried women to migrate southwards to Kumasi and Accra in search for non-existent jobs to cater for their needs. Unfortunately, most of them end up in vices like teenage pregnancy, prostitution and drug peddling.

\section{Widows}

Women who fail to re-marry within their ex-husband's family may have issues accessing land and real property of the deceased under custom unless they make claims under other legal regimes (such as the Intestate Succession Law). Thus, these women resort to borrowing or renting land on ridiculous conditions. They are also handicapped financially and are not able to contract people to help them on their farms to improve productivity. This makes it very hard for the women to take care of themselves and their children who mostly become their responsibility. Generally, land tenure insecurity discourages land conservation methods. Land fallowing may be misconstrued as land abandonment and in customary land tenure abandonment permits the land owner to regain possession. It also contributes to low productivity and aggravates food insecurity.

\section{Land Registration in the Wa Municipality}

The study also sought to determine the level of awareness on land registration. As shown in Table 3 below, majority of the male (64\%) and female (59\%) respondents had knowledge of land registration even though they do not have much knowledge of the processes involved. It was discovered that $45 \%$ male and $60 \%$ of women respondents held search reports and allocation notes believing they were land leases. This phenomenon is attributable to the low level of public education on the land documentation process and its importance. It was also established that $55 \%$ of male and $40 \%$ female respondents did not register their lands due to the associated high costs, time and bureaucracy involved in the registration.

To find out more on how many males and females registered their lands, data was collected from the Upper West Deeds Registry. It was discovered that more males than females registered their lands because they own most lands in the region and were financially sound to meet the cost on registration. Notably, it was reported that the situation has improved from previous years following the upgrading of the then Lands 
Commission (now Public and Vested Land Management Division) into a Deeds Registry under the Land Administration Project (LAP 1). This improvement can be seen in the Table 3 below.

Table 3: Responses on Registration of Lands

\begin{tabular}{|l|l|l|l|l|}
\hline Responses & $\begin{array}{l}\text { Number of } \\
\text { Male }\end{array}$ & $\begin{array}{l}\text { Percentage of } \\
\text { Male }\end{array}$ & $\begin{array}{l}\text { Number of } \\
\text { Female }\end{array}$ & $\begin{array}{l}\text { Percentage of } \\
\text { Female }\end{array}$ \\
\hline Yes & 40 & $64 \%$ & 52 & $59 \%$ \\
\hline No & 23 & $36 \%$ & 36 & $41 \%$ \\
\hline Total & 63 & 100 & 88 & $100 \%$ \\
\hline
\end{tabular}

Source: Field Survey, 2009

Subsequently, we also sought to examine how many titles were actually registered by males and females between 2005 and 2009 following the establishment of the deeds registry in the Wa Municipality. Table 4 below covers registered deeds from 2006 to 2008 in the Wa Deeds Registry. From the table, it is evident that more male as compared female registered deeds in the stated period. While 302 male registered deeds in 2006, only 44 female registered deeds within the same period. We discovered that some women preferred to register their lands in their sons' or brothers' names because they did not want to be perceived as rubbing shoulders with their male counterparts which the society frowns on. It was also revealed that the high cost of deeds registration was another disincentive for women to register acquired parcels of land.

It was also realised that within the same period, no deeds of gifts were registered by either male or females. From the Table 4, however, the number of deeds registered by women doubled from the 2007 figure (59) to 101 in 2008. This is due to their involvement in stakeholder discussions and workshops with gender-centred institutions and women groups in the Municipality at the time. This also reveals the important roles that public education stand to contribute to bridging the gender disparity in land ownership in the Wa Municipality.

\section{Table 4: Number of Registered Leases by Sex (2006-2008)}

\begin{tabular}{|l|l|l|l|}
\hline Year & Male & Females & Total \\
\hline 2006 & 302 & 44 & 346 \\
\hline 2007 & 355 & 59 & 414 \\
\hline 2008 & 381 & 101 & 482 \\
\hline
\end{tabular}

Source: Upper West Deeds Registry, 2009 


\section{Discussion of Findings}

There are a myriad of challenges militating against women's secure access to land for sustained production. Contrary to the findings of Kasanga and associates (1996) that the existing land tenure system does not present any significant challenges to women's ability to access agricultural land in a number of areas including Wa area, our study reveal that driven by population growth and urbanization, customary and land tenure practices are unleashing serious impediments on women's land access and economic effort. Our findings reaffirm those of Duncan and Brant, (2004); Duncan, (1997); Kotey and Tsikata, (1998) and Bortei-Doku (1997), among others.

The field survey revealed that most of the lands in the Wa Municipality belong to a group of all-male Tendamba. Men are the custodians of land and they have the primary responsibility of use and control over the lands. Men make land-based decisions and are not customarily obliged to consult women. Hardly do women own land in their natal or matrimonial homes. They only have restricted user rights. For instance, they are not entitled to grow tree crops without the permission of their grantors. Furthermore, this arrangement does not guarantee tenure security since such lands can be taken from them when needed for other purposes including selling out. It was also revealed that the patrilineal system of inheritance impede women's access to and ownership of lands in the Municipality.

Women in their natal homes are not given the opportunity to inherit family property because they are considered temporary members of the family. This is consistent with the remarks of Niessen (1985). Niessen opined that women are associated with both families but are not absolute members of either family and thus have no clearly defined social identity. Married women are seen as assets and helping hands to their families so do not own land since 'assets cannot own assets' (qualitative field data, 2009). A widow without children cannot benefit from the husband's land unless she decides to remarry any of the brothers of the deceased husband. Divorcees and widows face discrimination even when it comes to access to land (Bortei-Dorku, 1990).

The study further found out that the increasing commercialization of lands in the Municipality has enabled some women to buy residential lands from the emerging land market in urban Wa like their male counterparts. However, the comparative numbers between male and female are still too wide and cannot be completely conclusive of a reduction in gender disparity in accessing customary land. Though registered leases in the Wa Municipality from 2006 to 2008 revealed an improvement in residential lands registered, women's access to agricultural lands have not seen much improvements. Indeed, women tend to lose their marginal agricultural lands to the commodities market. Improving women's land access and ownership is vital to enable them make the needed contribution to food production, economic empowerment and also reduce their exposure to gender induced vulnerabilities. 


\section{Conclusion and Recommendations}

It can be concluded that women in the Wa Municipality do not have equal access to land. Their access is limited to user rights from their natal and matrimonial family lands. This access however does not give women control, alienation, sale, or rental rights without the permission of the family/clan head. Women only have secondary rights which are not capable of being registered and hence the current landholding system does not guarantee security of tenure for most women who only have user rights. It was also revealed that both men and women have equal opportunities to access commercial or residential land in the Wa Municipality through the land market.

Even though women are not prevented from buying these lands, most of them do not have the required capital to acquire their own lands. Our study confirmed that customary factors impede women's access and ownership of land in the Wa Municipality. It revealed that customary practices on ownership, inheritance and sacrifices to land gods and ancestors are stumbling blocks on women's access and ownership of land in the Wa Municipality. Furthermore, factors such as financial constraints, rapid urbanization and high illiteracy rate among women also impede women land ownership in the Wa Municipality. Based on the findings summarised supra, there is a wide disparity between women and men with regard to ownership and access to land in the Wa Municipality. Ownership and access are skewed in favour of the men. The situation above is explained with the conception then that since "women are assets and assets do not own assets", women do not own customary land in the Wa Municipality.

There is the need for central and local governments to enact policies aimed at empowering women economically through a guaranteed land rights and equal economic opportunities. NGOs already working in this area should intensify their efforts towards the formation of women groups in various communities and make available to them capital and other training on investment opportunities, entrepreneurial skills and good farm practices. Economic empowerment will then be a tool to equitable land market participation.

It is further recommended that seminars and workshops be organised by the Land Sector Agencies (LSAs) and relevant Non-Governmental Organisations (NGOs) for the chiefs, family heads and elders in the communities to educate them on the importance of women's access to and ownership of lands. This would also make them flexible to amend their customary rules so that both men and women can have access and own family lands. The Lands Commission should embark on public education to inform people in the Municipality of the importance of land registration and the processes involved. This could make the process both cost and time effective and bearable. The efforts of the Lands Commission in this regard can feed into existing projects on streamlining land registration in Ghana under the Land Administration Project (LAP). These recommendations would not necessarily alter customs and traditions relating to the ownership of customary land, but can re-awaken consciousness in the leadership of the 
customary setup particularly among Tendamba and family heads who are principal actors in land ownership and transfer in the Wa Municipality.

\section{REFERENCES}

Adiaba, S.Y. (2006). "Gender Disparity with respect to Access and Ownership of Land: A Myth or a Reality? A Case study of the Gurunsi in the Upper East Region," A Paper prepared for the Ghana Institution of Surveyors, Accra.

Agarwal, B. (1989). Rural Women, Poverty and Natural Resources: Sustenance, Sustainability and Struggle for Change, Economic and Political Weekly, Vol.XXIV No.43: 46-69.

Ahene, R. A. (2009). Measures to Improve Access to Land Resources and Related Benefits in Uganda, Lafayette College, Easton PA.

Bortei-Dorku, E. (1990). Profile of Women in Ghana, CIDA, Accra.

Bortei-Doku A., E., (1997). "Behind the Norms: Women's Access to Land in Ghana”, In C. Toulmin, Phillippe Lavigne Delville, \& Samba Traore (Eds). The Dynamics of Resource Tenure in West Africa, IIED: 86.-97.

Bugri J.T. (2008). The dynamics of tenure security, agricultural production and environmental degradation in Africa: Evidence from stakeholders in the North East Ghana, Land Use Policy, Vol. 25 (2), pp271-285.

Dowuona-Hammond, c. (2003). "Report on State Land Management and Its Impact on Women and the Poor in Ghana." GTZ Legal Pluralism and Gender Project (Land Law Focal Area), Accra, Ghana

Duncan B.A., (2000). Women in Agriculture in Ghana, Accra, GH: Friedriech Ebert Foundation.

Duncan B.A and Brants, C. (2004). "Access to Land and Control Over Land from a Gender Perspective: A study conducted in the Volta Region." Commissioned by SNV - Ghana Office and the Gender and Development Unit of FAO of the U.N. Regional Office for Africa (FAORAF).

FAO (2002). “Gender and Access to Land," Land Tenure Studies 4: Food and Agricultural Organisation of the United Nations, Viale delle Terme di Caracalla, Rome, Italy.

FAO (2005). Land tenure studies. Access to rural land and administration after conflicts. Rome. Italy. 
Gray, L. and Kevane, M. (1992). Diminished Access, Diverted Exclusion: Women and Land Tenure in Sub-Saharan Africa. Project on Gender and Property Rights in Africa. The World Bank, Washington DC.

GSS (2012). 2010 Population and Housing Census, Ghana Statistical Service, Accra.

Hilhorst, T. (2000). Women's Land Rights: Current Development in Sub-Saharan Africa. In Toulmin C. and Quan, J. (editors). Evolving Land Rights, Policy and Tenure in Africa, DFID/IIED/NRI, London.

IFAD, (1998). Improving Women's access to land in the Upper East, Mid-Term Evaluation Report on Land Conservation and Small-holder Rehabilitation Project (LACOSREP), Ministry of Food and Agriculture, Bolgatanga, Ghana (Online) Available at http:// www.ifad,org/gender/lerning/resouces/natural/40.htm. Accessed on 21st July, 2007.

IFAD (2005). Gender and Natural Resource Management: Gender and Land Compendium of Country studies, IFAD.

IIED (1999). Land Tenure and Resource Access in West Africa: Issues and Opportunities for the Next Twenty Five Years, International Institute for Environment and Development (IIED), a Working Paper presented to Department for International Development (DFID), UK.

ISSER (2003). Land Ownership Systems and Security of Tenure and Rights Associated with Customary Grants in Ghana, ISSER, Accra.

Kasanga, R. K., Cochrane, J., King, R. \& Roth, M. (1996). Land markets and legal contradictions in the peri-urban area of Accra, Ghana: Informant interviews and secondary data investigations, Land Tenure Centre Research Paper 127, University of Wisconsin Madison, USA.

Kameri-Mbote, P. (2005). The Land has Its Owners!; Gender Issues in Law Tenure Under Kenya Customary Law, International Environmental Law Research Centre Working Paper, 2005-9, http://www.ielrc.org/content/w0509.pdf, Accessed, August 28, 2012.

Kunbuor, B. (2000). Customary Law of the Dagaare in Northern Ghana: Indigenous Rules or a Social Construction. Journal of Dagaare Studies, Vol. 2,p1-20.

Kuusaana, E. D. (2007). Land Dispute Resolution: the role of Chiefs and Tendamba. Case Study of Wa Municipality. Unpublished undergraduate thesis presented to the Department of Land Economy, KNUST, Kumasi.

Kotey, E. N. A. \& Tsikata, D. (1990), "Women and Land Rights in Ghana" in Kuenyehia, A. (ed.). Women and Law in West Africa: Situational Analysis of Some Key Issues Affecting Women, Accra, WaLWA: 203-216. 
Manu, T. (1984). "Law and the Status of Women in Ghana", paper prepared for the UN Economic Commission on Africa.

Ministry of Justice (2003). Peri-Urbanism, Land Relations and Women in Ghana, Access to Justice Series, No. 1, Ghana Publishing Corporation (Assembly Press), Accra.

Ministry of Justice (2003). State Land Management Regime. Impact on land rights of Women and the Poor in Ghana, Access to Justice Series, No 2, Ghana Publishing Corporation (Assembly Press).

Niesssen, S.A. (1985). Motif of Life in Tobak Text and Textiles, Foris Publications, Dordrecht, Holland.

Ostrom, E. and Hess, C. (2007). Private and Common Property Rights, Workshop in Political Theory and Policy Analysis, Indiana University.

Owusu, G.; Kwami, E. and Tagoe, A. c. (2007). Gender, Land Tenure Dynamics and Livelihood in the Central and Volta Regions of Ghana, ISSER, Accra.

Quist, E. (undated). Women's Access, Control and Tenure of Land, Property and Settlement. (Online) Available at

http://www.sli.unimelb.edu.au/fig7/Brightong8/Comm7Papers/TS26-Qvist.html, last assessed on $22 n d$ July, 2007.

Quisumbing, A.R.; Agnes E.; Aidoo J.B. and Otsuka, K. (1999). Women's Land Rights in Transition to Individualised Ownership. Implications for the Management of tree resources in Western Ghana. IFPRI, Washington.

Sewornu, R.E. (2010). “The Role of Good Governance in Improving Women's Access Right to Customary Land in Ghana." Unpublished MSc. thesis submitted to the Chair of Land Management, TUM, Germany.

Toulmin, C. \& Quan, J. (200o). "Evolving Land Rights, Policy and Tenure in Africa," DFID/ IIED/NRI. 